\title{
Quality effects on beef strip steaks from cattle fed high-protein corn distillers grains and other ethanol by-products
}

\author{
Kellen B. Hart, Felipe A. Ribeiro, Morgan L. Henriott, Nicolas J. Herrera, and Chris R. Calkins ${ }^{1}$ \\ Department of Animal Science, University of Nebraska-Lincoln, Lincoln, NE 68583-0908
}

\begin{abstract}
The objective of this study was to evaluate the effects of feeding high-protein corn distillers grains on fresh beef quality. Steers $(n=60)$ were fed one of five diets for $190 \mathrm{~d}$ (six pens with 10 cattle/pen/diet): a corn control (Control), 40\% high-protein dry distillers grains plus solubles (HP-DDGS), 40\% dry distillers grains plus solubles (DDGS), 40\% wet distillers grains plus solubles (WDGS), or $40 \%$ bran plus solubles (Bran). Eighteen Choice carcasses (three cattle per pen) were randomly selected within each treatment; however, two carcasses were lost during carcass selection. Strip loins (Longissimus lumborum, IMPS \# 180) were collected, divided into three equal portions, and aged for 2, 9, or $23 \mathrm{~d}$. Steaks were fabricated following each aging period and placed under retail display (RD) conditions for 0,4 , or $7 \mathrm{~d}$. Pen was the experimental unit. Hot carcass weight at harvest was $391 \mathrm{~kg}$ (SD $31.6 \mathrm{~kg}$ ). Dietary treatment had no effect on tenderness (Warner-Bratzler shear force) within each aging period $(P>0.05)$. After $7 \mathrm{~d}$ of $\mathrm{RD}$, following all aging periods, steaks from cattle fed HP-DDGS had the greatest visual discoloration except for DDGS and Bran after $23 \mathrm{~d}(P<0.05)$. The steaks from cattle fed HP-DDGS had lower
\end{abstract}

$(P<0.05)$ redness $\left(a^{*}\right)$ values than all other treatments following $7 \mathrm{~d}$ of RD. Lipid oxidation increased $(P<0.001)$ during RD at all aging periods, as measured via thiobarbituric acid reactive substance (TBARS). A day of RD-by-dietary treatment effect $(P<0.001)$ was observed for lipid oxidation. After $7 \mathrm{~d}$ of RD, steaks from cattle fed HP-DDGS had higher TBARS than all other treatments except WDGS $(P<0.01)$. A trend was found for sarcomere length $(P=0.07)$, with steaks from cattle fed Bran having the longest sarcomere length compared with all other treatments. An aging effect was found for free calcium content $(P<0.001)$ where steaks aged 9 and $23 \mathrm{~d}$ had significantly higher levels of free calcium than those aged $2 \mathrm{~d}$. There was a tendency $(P=0.07)$ that steaks from cattle fed WDGS contained more free calcium than steaks from cattle fed DDGS or Bran. Although there were no statistical differences, there was a trend $(P=0.07)$ that steaks from cattle fed HP-DDGS had higher levels of PUFAs and C18:2. These results suggest that feeding high protein distillers grains has no detriment on tenderness, but may alter the lipid profile of the muscle, resulting in decreased color stability, increased lipid oxidation, and decreased shelf life.

Key words: beef, distillers grains, fatty acid composition, high protein

(C) The Author(s) 2019. Published by Oxford University Press on behalf of the American Society of Animal Science. All rights reserved. For permissions, please e-mail: journals.permissions@oup.com.

J. Anim. Sci. 2019.97:2087-2098 doi: 10.1093/jas/skz086

\section{INTRODUCTION}

Distillers grains, a byproduct of corn ethanol production, have been used as a livestock feedstuff

${ }^{1}$ Corresponding author. ccalkins1@unl.edu

Received December 6, 2018.

Accepted March 11, 2019. for over 100 years (Klopfenstein et al., 2008). As the ethanol industry continues to evolve to maximize profits, new co-products are being produced. One of the newest methods used in the ethanol industry is a process known as dry or front-end fractionation. Dry fractionation is the process of physically separating corn into its three fractions (endosperm, bran, and germ) prior to the fermentation process. 
Removing the nonfermentable germ, which contains $85 \%$ of the corn oil, allows ethanol producers to remove the oil for other markets and creates more capacity for fermentation of starches. Additionally, the removal of this corn oil can decrease the lipid content of the resulting distillers grains (U.S. Grains Council, 2012). The bran will also not be introduced into the ethanol production process due to its nonfermentable nature and can be combusted for energy or sold as a livestock feed (Cereal Process Technologies, 2018). The removal of these two fractions increases the total amount of fermentable starch available during ethanol production (Ponnampalam et al., 2004). With only the endosperm being fermented, there are lower costs associated with the production of the distillers grains as a result of lower energy costs of drying and a greater stream of co-products (Rendleman and Shapouri, 2007). The resulting distillers grains from this method have been referred to as high-protein dried distillers grains (HP-DDGS). It is believed that the higher level of CP present is due to more efficient fermentation (Robinson et al., 2008). Lipid content of traditional dried distillers grains plus solubles (DDGS) has been reported at $8 \%$ to 9\%, while HP-DDGS can have a lipid level of closer to $4 \%$, on a DM basis (Ganesan et al., 2009; Cereal Process Technologies, 2016).

Previous research has shown that feeding cattle with diets containing distillers grains can alter the fatty acid profile by increasing the content of PUFAs and linoleic acid, resulting in increased lipid oxidation and decreased color stability (Mello et al., 2012; Chao et al., 2017; Domenech-Perez et al., 2017; Ribeiro et al., 2018). Atkinson et al. (2006) concluded that feeding diets higher in PUFA can decrease ruminal biohydrogenation leading to more unsaturated fatty acids present in tissue. Similar results were presented by Zinn et al. (2000) who concluded that as unsaturated fatty acids are increasingly more available within the rumen, bile salt micelles will cover more surface area, causing a decrease in ruminal biohydrogenation, and allow for more efficient digestibility and absorption of unsaturated fats. It is well known that meat containing higher levels of unsaturated fatty acids are more readily oxidized (Nute et al., 2007; Faustman et al., 2010; Mello et al., 2012; Ribeiro et al. 2018). Meat from animals fed higher proportions of PUFA's has been shown to contain more unsaturated fatty acids and be more susceptible to lipid oxidation, with increased levels of discoloration (Nute et al., 2007).

Chao et al. (2017) showed that feeding distillers grains resulted in higher PUFA content in the lean and within the sarcoplasmic reticulum, the organelle that controls calcium within the cell. As a result, they (Chao et al., 2017) hypothesized that calcium was released within the cell earlier postmortem, thereby activating calpains and enhancing proteolysis, which would enhance tenderness. Others have also indicated that there may be an improvement in tenderness of the meat (Gordon et al., 2002; Depenbusch et al., 2009; Senaratne, 2012). Therefore, a full understanding of how the inclusion of high-protein distillers grains in cattle diets affects meat quality is imperative. More specifically, the objectives of this study were to evaluate how high-protein distillers grains affect tenderness, fatty acid profile of the muscle, and retail display (RD) as related to discoloration and lipid oxidation of beef.

\section{MATERIALS AND METHODS}

All procedures related to live animals for this study were approved by the Institutional Animal Care and Use Committee of the University of Nebraska-Lincoln (IACUC \#1282).

\section{Cattle and Dietary Treatments}

A total of 300 cross-bred calf-fed steers (initial $\mathrm{BW}=282 \pm 10 \mathrm{~kg}$ ) were fed (Eastern Nebraska Research and Extension Center feedlot in Mead, NE) for $190 \mathrm{~d}$ on either a corn control diet (Control) or a diet containing 40\% HP-DDGS, 40\% DDGS, 40\% WDGS, or $40 \%$ bran plus solubles (Bran). Inclusion rate of distillers grains were calculated on a DM basis. Steers were fed 50\% Sweet Bran (Cargill, Blair, $\mathrm{NE}$ ) and $50 \%$ alfalfa hay at $2 \%$ of BW for $5 \mathrm{~d}$ to identify initial BW for the trial. Steers were blocked and stratified by BW prior to being randomly assigned to a pen. Pens were randomly assigned to one of five treatments with 10 steers/pen and six pens/treatment resulting in a total of 30 pens. High-protein DDGS and Bran were sourced from the same ethanol plant (Corn Plus, Winnebago, MN). Traditional WDGS and DDGS were sourced from E Energy (Adams, NE) and KAAPA Ethanol (Ravenna, NE), respectively. All diets contained $15 \%$ corn silage and 5\% supplement containing $30 \mathrm{mg} / \mathrm{kg}$ Rumensin (Elanco Animal Health, Greenfield, IN) and $8.8 \mathrm{mg} / \mathrm{kg}$ Tylan (Elanco Animal Health). On day 1, steers were implanted with Revalor XS (Merck Animal Health, DeSoto, KS).

\section{Sample Collection and Fabrication}

All cattle were harvested at Greater Omaha Packing Co. in Omaha, NE. On day 2 postmortem, three low Choice carcasses per pen were identified 
for a total of 18 low Choice carcasses within each treatment $(n=18)$. Quality grade was determined via a USDA-approved camera and lipid composition was subsequently measured (see Proximate Composition section). During carcass selection, two carcasses were lost resulting in a final count of 88 carcasses. The two carcasses lost included one from the Bran treatment and one from the WDGS treatment. Strip loins (Longissimus lumborum, IMPS \# 180, NAMP, 2011) from the right side of the carcasses were collected. Identified loins were vacuum packaged and transported to the Loeffel Meat Laboratory at the University of NebraskaLincoln. Strip loins were divided into three equal sections, and each section was randomly assigned to one of the three aging periods $(2,9$, or $23 \mathrm{~d})$ immediately after arrival at the Loeffel Meat Laboratory $2 \mathrm{~d}$ postmortem. Three $2.54 \mathrm{~cm}$ steaks were fabricated at each aging period (one steak to measure Warner-Bratzler shear force at $0 \mathrm{~d}$ of RD, one steak to measure Warner-Bratzler shear force, daily visual discoloration, and daily instrument color, and one steak was cut in half and trimmed of all subcutaneous fat and analyzed for lipid oxidation for $0 \mathrm{~d}$ of $\mathrm{RD}$ and all other laboratory analysis). One $1.27 \mathrm{~cm}$ steak was cut in half, trimmed of all subcutaneous fat, and analyzed for lipid oxidation after 4 and $7 \mathrm{~d}$ of RD. At day 2, steaks for laboratory analysis, lipid oxidation steaks for $0 \mathrm{~d}$ of $\mathrm{RD}$, and all remaining sections of loins were vacuum packaged in Prime Source Vacuum pouches ( 3 mil STD barrier, Prime Sources, St. Louis, MO). Steaks for laboratory analysis and lipid oxidation were frozen for further analysis $\left(-80^{\circ} \mathrm{C}\right)$. The remaining portions of loins were aged $\left(2^{\circ} \mathrm{C}\right)$ under dark storage. All steaks were separated from the loin from the anterior to posterior end of the loin. The same fabrication scheme was used for all aging periods. At all aging periods, samples for tenderness, color, and lipid oxidation analysis were placed on foam trays $(21.6 \times 15.9 \times$ $2.1 \mathrm{~cm}$, Styro-Tech, Denver, CO) and overwrapped with an oxygen permeable film (Prime Source PSM 18 \#75003815, Bunzl Processors Division, North Kansas City, MO). Trays were placed under simulated RD conditions on tables in a meat cooler for 4 and $7 \mathrm{~d}\left(3^{\circ} \mathrm{C}\right.$ under white fluorescence lighting at 1,000 to 1,800 lux; Lamp type: F32T8/TL741 700 Series 32 watt, Phillips, Inc., New Jersey) and randomly rotated daily. All frozen steaks utilized for laboratory analysis and lipid oxidation were tempered enough to finely dice, frozen in liquid nitrogen and then homogenized in a metal cup blender (Model 51BL32, Waring Commercial, Torrington, CT) and held at $-80^{\circ} \mathrm{C}$ until further analysis.

\section{pH Analysis}

Powdered sample from steaks from all aging periods with $0 \mathrm{~d}$ RD was weighed out in $10 \mathrm{~g}$ duplicates into $250 \mathrm{~mL}$ plastic beakers and placed on a stir plate. Ninety milliliters of distilled deionized water and a magnetic stir bar were added to ensure constant mixing during the measurement process. The $\mathrm{pH}$ was measured using a $\mathrm{pH}$ meter (Orion 410Aplus: ThermoFisher Scientific, Waltham, MA) that was calibrated using 4.0, 7.0, and 10.0 standards. The mean measurement of the duplicates was utilized for all analysis.

\section{Proximate Composition}

Moisture, fat, and ash (\%) of raw meat samples were determined. Moisture and ash (\%) were quantified with a LECO Thermogravimetric Analyzer in duplicate (Model 604-100-400, LECO Corporation, St. Joseph, MI). Total fat (\%) was determined in triplicate by ether extraction according to the Soxhlet procedure (AOAC, 1990). Protein was determined by difference.

\section{Sarcomere Length}

Sarcomere length was determined using the helium-neon laser diffraction method described by Cross et al. (1981) and Dolazza and Lorenzen (2014). A few flecks of powdered meat sample were placed on a clear glass microscope slide. A single drop of $0.25 \mathrm{M}$ sucrose solution was added to the slide and topped with a glass coverslip. The distance to the top of the slide from the base of the laser was $100 \mathrm{~mm}$. A sheet of paper was placed below the stand to mark the two diffraction bands. Sarcomere lengths (six per sample) were calculated by the equation provided by Cross et al. (1981).

\section{Free Calcium Concentration}

Free calcium was quantified according to the procedure described by Parrish et al. (1981) with modifications as described. Three grams of powdered sample were centrifuged $(196,000 \times g)$ at $4{ }^{\circ} \mathrm{C}$ for $30 \mathrm{~min}$. Seven hundred microliters of the supernatant were collected and treated with $0.1 \mathrm{~mL}$ of $27.5 \%$ trichloroacetic acid (TCA). Samples were centrifuged $(6,000 \times g)$ for $10 \mathrm{~min}$. Four hundred microliters of supernatant were transferred to a syringe, and the volume was brought to $4 \mathrm{~mL}$ with deionized, distilled water. The diluted sample was filtered through a 13-mm diameter Millex-LG 
$0.20 \mu \mathrm{m}$ syringe filter (Milliore, Bedford, MA). Calcium concentration was quantified at Ward Laboratories (Kearney, NE) using an inductively coupled plasma emission spectrometer (iCAP 6500 Radial; Thermo Electron, Cambridge, UK) with appropriate calcium concentration standards.

\section{Tenderness Determination}

Steaks $(2.54 \mathrm{~cm})$ were measured for tenderness via Warner-Bratzler shear force (WBSF). Internal temperature and weight were measured prior to cooking using a quick disconnect T-type thermocouple (TMQSS-062U-6, OMEGA Engineering, Inc., Stamford, CT) and a handheld thermometer (OMEGA 450-ATT, Engineering, Inc.) in the geometric center of the steaks. All steaks were cooked to an internal temperature of $35^{\circ} \mathrm{C}$ and turned over until they reached a target temperature of $70^{\circ} \mathrm{C}$ on an indoor electric grill (Hamilton Beach-31605A, Hamilton Beach Brands, Glen Allen, VA). After cooking final weights were recorded. The steaks were then bagged individually (PB-90-C, 0.85 mil, $15.2 \times 7.6 \times 38.1 \mathrm{~cm})$ and stored overnight at $2{ }^{\circ} \mathrm{C}$ and the following day, six $(1.27 \mathrm{~cm}$ diameter $)$ cores were removed with a drill press parallel to the muscle fibers and sheared using a Food Texture Analyzer $(250 \mathrm{~mm} / \mathrm{min}$ blade speed, TMS-Pro, Food Technology Corp., Sterling, VA) with a triangular Warner-Bratzler blade $(250 \mathrm{~mm} / \mathrm{min}$ blade speed). The mean shear force of the six cores was calculated for statistical analysis.

\section{Fatty Acid Analysis}

Total lipids were extracted using the chloroform-methanol procedure by Folch et al. (1957). After extraction, lipids were converted to fatty acid methyl esters according to Morrison and Smith (1964) and Metcalfe et al. (1966). One gram of powdered sample was homogenized with $5 \mathrm{~mL}$ of 2:1 chloroform:methanol and allowed to sit at room temperature $\left(23^{\circ} \mathrm{C}\right)$ for $1 \mathrm{~h}$. After, samples were filtered through Whatman \#2 paper, brought up to a final volume of $10 \mathrm{~mL}$ with 2:1 chloroform:methanol, and vortexed for $5 \mathrm{~s}$ with $2 \mathrm{~mL}$ of $0.74 \% \mathrm{KCl}$. Samples were centrifuged $(1,000 \times g$ for $5 \mathrm{~min})$ and the top layer was aspirated off. After centrifugation, samples were dried on a heating block at $60{ }^{\circ} \mathrm{C}$ under nitrogen purge. Once dry, $1 \mathrm{~mL}$ of 0.5 $\mathrm{M} \mathrm{NaOH}$ in methanol was added, vortexed (5 s), and heated at $100{ }^{\circ} \mathrm{C}$ for $10 \mathrm{~min}$. One milliliter of $14 \%$ boron trifluoride in methanol was added, vortexed $(5 \mathrm{~s})$, and again heated at $100{ }^{\circ} \mathrm{C}$, this time for 5 min. Two milliliters of a saturated salt solution and $2 \mathrm{~mL}$ of hexane was added and vortexed $(5 \mathrm{~s})$. Samples were then centrifuged $(1,000 \times g$ for $5 \mathrm{~min}$ ) and the hexane layer removed and analyzed using gas chromatography (TRACE 1310 Gas Chromatograph; ThermoFisher Scientific). Fatty acids were separated using a Chrompack CP-Sil 88 capillary column $(0.25 \mathrm{~mm}$ by $100 \mathrm{~m}$; Inlet temp: $260{ }^{\circ} \mathrm{C}$, Oven: $140{ }^{\circ} \mathrm{C}$ hold for $5 \mathrm{~min}$, increase at $4{ }^{\circ} \mathrm{C} / \mathrm{min}$ to $240^{\circ} \mathrm{C}$ and hold for $15 \mathrm{~min}$. FID temp: $280^{\circ} \mathrm{C}$. Injected at 30:1 ratio) and identified based on their retention times compared with known commercial standards (NU-Check Prep, Inc., Elysian, MN; \# GLC-68D, GLC-79, GLC-87, GLC-455, and GLC-458). The percentage of fatty acids was determined by the peak areas in the chromatograph and values were converted to $\mathrm{mg} / 100 \mathrm{~g}$ tissue:

Fatty acid $\mathrm{mg} / 100 \mathrm{~g}$ tissue $=(\%$ of fatty acid peak area $\times$ fat content of samples $) \times 1,000$

\section{Lipid Oxidation (thiobarbituric acid reactive substance, TBARS)}

Lipid oxidation was determined using TBARS method for samples at 0,4 , and $7 \mathrm{~d}$ of RD at all aging periods, according to Ahn et al. (1998). Five grams of powdered meat were placed into a $50-\mathrm{mL}$ conical tube to which $14 \mathrm{~mL}$ of distilled deionized water and $1 \mathrm{~mL}$ of butylated hydroxyanisole (BHA) solution (10\% BHA: $90 \%$ ethanol) were added. Samples were homogenized using a Polytron (POLYTRON Kinimatica CH-6010, Switzerland) for $15 \mathrm{~s}$ at medium-to-high speed. The samples were centrifuged $\left(2,000 \times g\right.$ for $5 \mathrm{~min}$ at $\left.10^{\circ} \mathrm{C}\right)$ and $1 \mathrm{~mL}$ of supernatant was transferred into a $15-\mathrm{mL}$ conical tube with $2 \mathrm{~mL}$ of 2,4,6-tribromoanisole (TBA) TCA solution (15\% TCA and $20 \mathrm{mM}$ TBA in deionized distilled water). Tubes were then placed in a $70{ }^{\circ} \mathrm{C}$ water bath for $30 \mathrm{~min}$. Tubes were cooled for at least $10 \mathrm{~min}$ in a water bath $\left(22^{\circ} \mathrm{C}\right)$ and centrifuged $\left(2,000 \times g\right.$ for $15 \mathrm{~min}$ at $\left.10^{\circ} \mathrm{C}\right)$. Two hundred microliters of supernatant were transferred to a 96-well plate in duplicate. Absorbance values were then read at $540 \mathrm{~nm}$ using a microplate spectrophotometer (Model Epoch, Biotek, Winooski, VT). Results were expressed in milligram of malonaldehyde per kilogram of tissue.

\section{Instrument Color}

Instrument color measurements were made once daily during each day of RD at all aging time points. Commission internationale de l'éclairage $L^{*}, a^{*}$, and $b^{*}$ values were obtained using a 
Minolta CR-400 colorimeter (Minolta, Osaka, Japan) set with a D65 illuminant, $2^{\circ}$ observer, with an $8 \mathrm{~mm}$ diameter measurement area. Six measurements were made per steak, and the mean was calculated for statistical analysis. The colorimeter was calibrated daily with a white ceramic tile (Calibration Plate, Serial No. 14933058, Konica Minolta, Japan). Color readings were recorded at the same time each day (1600 hours).

\section{Visual Discoloration}

Visual discoloration was assessed daily during the $7 \mathrm{~d}$ of RD utilizing five trained panelists comprised of graduate students from the University of Nebraska-Lincoln. Discoloration percent was approximated from $0 \%$ to $100 \%$ with $0 \%$ meaning no discoloration present and $100 \%$ being a fully discolored steak. A reference guide showing discoloration in $20 \%$ increments $(0 \%, 20 \%, 40 \%, 60 \%, 80 \%$, and $100 \%$ discoloration) was provided to panelists to ensure consistent evaluation of steak discoloration. All measurements from panelists were averaged for each steak. Steaks were randomly rotated daily to minimize location effects. Panelists were trained using a standardized discoloration guide.

\section{Statistical Analysis}

Statistical analyses were conducted with SAS (version 9.4, Cary, NC). Instrument and visual color data were analyzed as a split-plot repeated measures design with dietary treatment as the whole plot, aging period as the split plot and RD time as the repeated measures. Tenderness and lipid oxidation data were analyzed as a split-split-plot design with treatment as the whole-plot, aging period as the splitplot and RD time as the split-split-plot. Proximate composition and sarcomere length were analyzed as a completely randomized design. Free calcium and $\mathrm{pH}$ were analyzed as $5 \times 3$ factorial arrangement of dietary treatments by aging period. Data were analyzed using the PROC GLIMMIX procedure of SAS and pen was the experimental unit. All means were separated with the LS MEANS statement and the TUKEY adjustment, with an alpha level of 0.05 . Relevant trends are discussed when $P<0.10$.

\section{RESULTS AND DISCUSSION}

\section{pH}

There were no differences among treatments for pH. An aging effect was found for $\mathrm{pH}(P<0.001)$.
However, the difference in values was likely of little practical significance $(5.482 \mathrm{~d}, 5.449 \mathrm{~d}$, and $5.4923 \mathrm{~d}$, respectively).

\section{Proximate Composition}

In this study, dietary treatment had no effect $(P>0.05)$ on proximate composition of steaks or marbling scores (Table 1). The grade distribution of all 300 carcasses was: 1.4\% low Prime, $4.4 \%$ high Choice, $23.3 \%$ average Choice, $45.6 \%$ low Choice, and $25.3 \%$ Select. The mean values for the proximate composition of the 88 samples tested were: $71.31 \%$ moisture, $19.99 \%$ protein, $6.89 \%$ fat, and $1.81 \%$ ash. Other studies have also shown that the supplementation of distillers grains in multiple forms and inclusion levels does not alter the proximate composition of beef (Mello et al., 2012; Domenech-Perez et al., 2017; Ribeiro et al., 2018). However, Segers et al. (2011) concluded that steaks from steers fed DDGS tended to have higher moisture levels than those fed corn gluten feed, and Buttrey et al. (2013) found that steers fed a $35 \%$ inclusion of WDGS had steaks that tended $(P<0.10)$ to have greater fat content compared with steaks from cattle not fed WDGS.

\section{Sarcomere Length}

Sarcomere lengths differed with a $P$-value of 0.07 , where sarcomeres from steaks from cattle fed Bran were slightly longer than all other treatments; however, this increase in length did not relate to an increase in tenderness from steaks from cattle fed the Bran treatment. The mean sarcomere length of strip loins from cattle fed Control, WDGS, Bran, DDGS, and HP-DDS were 1.67, 1.69, 1.74, 1.69, and $1.69 \mu \mathrm{m}$, respectively (Figure 2). Wheeler and Koohmaraie (1999) report that sarcomere length from nonshortened LD was $1.69 \mu \mathrm{m}$, compared with those that were cold shortened, at $1.36 \mu \mathrm{m}$. Other studies focusing on the feeding of distillers grains have also reported no differences in sarcomere length (Chao et al., 2017; Ribeiro, 2017).

\section{Free Calcium Concentration}

There were no statistical differences $(P=0.07)$ in free calcium content among dietary treatments, but there was a tendency where steaks from WDGS had the greatest free calcium levels and Bran steaks the lowest (68.15 and $62.05 \mu \mathrm{M}$, respectively). As aging increased, there was a significant increase of free calcium levels in the meat $(P<0.001)$ (2 d:60.06 $\mu \mathrm{M}$; 9 d: $66.27 \mu \mathrm{M} ; 23 \mathrm{~d}: 67.82 \mu \mathrm{M}$ ). 
Table 1. Proximate composition ${ }^{1}$ of strip loin steaks

\begin{tabular}{lccccc}
\hline \hline Treatment & Moisture & Fat & Ash & Protein $^{3}$ & Marbling score $^{4}$ \\
\hline Control & 71.16 & 7.03 & 1.74 & 20.06 & 19.79 \\
WDGS $^{5}$ & 71.02 & 7.38 & 1.81 & 19.93 & 463 \\
Bran $^{5}$ & 71.76 & 6.47 & 1.85 & 20.44 & 454 \\
DDGS $^{5}$ & 71.25 & 6.49 & 1.82 & 19.72 & 480 \\
HP-DDGS $^{5}$ & 71.36 & 7.07 & 1.85 & 0.13 & 461 \\
P-value & 0.71 & 0.51 & 0.74 & 0.53 & 0.69 \\
SEM & 0.90 & 1.05 & 0.14 & 14.5 \\
\hline
\end{tabular}

${ }^{1}$ There were no differences among treatments $(P>0.05)$.

${ }^{2}$ Three cattle per pen were selected.

${ }^{3}$ Protein was calculated by subtracting the sum of moisture, fat, and ash from 100 .

${ }^{4} 400=$ small $^{0}, 500=$ modest $^{0}$.

${ }^{5}$ WDGS = wet distillers grains plus solubles, Bran = corn bran plus solubles, DDGS = dried distillers grains plus solubles, HP-DDGS = high-protein distillers grains plus solubles.

$n=18 /$ treatment

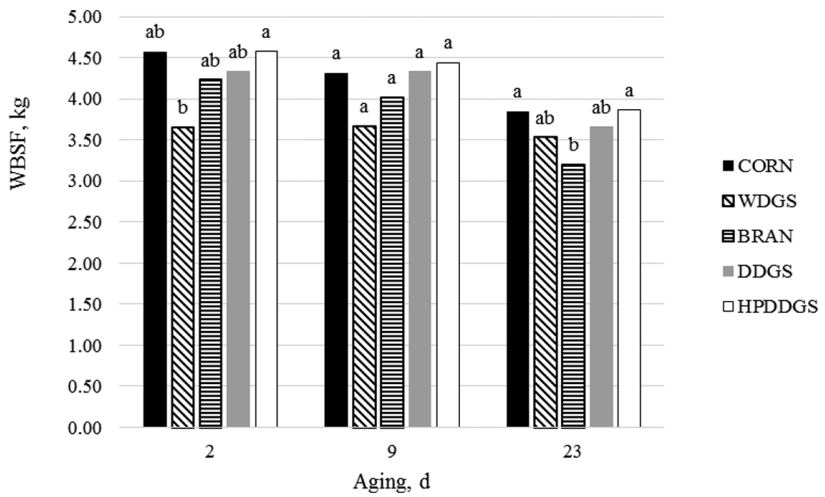

Figure 1. Warner-Bratzler shear force (WBSF) of strip loins steaks with $0 \mathrm{~d}$ retail display. Superscripts within the same aging period are different $(P>0.05$; SEM day $2=0.24$, SEM day $9=0.26$, SEM day $23=0.17)$.

\section{Tenderness Determination}

A significant aging time-by-dietary treatment effect $(P=0.01)$ was seen. There were no differences $(P>0.05)$ in tenderness between HP-DDGS and Control within aging periods. These results are in agreement with Popowski (2011) who found that steaks from steers fed 35\% HP-DDGS did not differ $(P=0.25)$ from steaks from steers fed either a corn control diet or 35\% DDGS after $2 \mathrm{~d}$ of aging. In the present study, meat from cattle fed WDGS was more tender after $2 \mathrm{~d}$ of aging than meat from cattle fed HP-DDGS. Steaks from cattle fed WDGS tended to have decreased (numerically lower) shear force values compared with steaks from cattle fed all other treatments after $2 \mathrm{~d}$ of aging $(P=0.08)$. This is consistent with Chao et al. (2017), who reported that at $2 \mathrm{~d}$ of aging, steaks from cattle finished with WDGS were more tender than steaks fed a corn control diet, but there was no difference as aging time increased. We have no explanation as to why HP-DDGS did not respond in a similar manner, although the lack of differences in sarcomere lengths and free calcium would support the lack of a difference in tenderness. An RD effect $(P<0.001)$ was identified. As expected, placing steaks in RD for 7 $\mathrm{d}$ increased tenderness for steaks aged 2, 9, and 23 $\mathrm{d}(P<0.001)$.

\section{Fatty Acid Profile}

The fatty acid profiles of all the dietary treatments are reported in $\mathrm{mg} / 100 \mathrm{~g}$ of tissue basis (Table 2). Differences $(P<0.05)$ were found in the amount of margaric acid $(\mathrm{C} 17: 0)$ present in the muscle across dietary treatments. Amount of C17:0 was greatest in beef from cattle fed WDGS, intermediate in beef from cattle fed Control, and lowest in beef from cattle fed HP-DDGS, Bran, and DDGS. Mello et al. (2012) also noted that steaks from cattle supplemented with 15\% WDGS had greater levels of C17:0 compared with steaks from cattle fed Control. Popowski (2011) reported that back fat from HP-DDGS contained a greater concentration of $\mathrm{C} 17: 0$ than fat from DDGS, but was not different than fat from cattle fed a corn control. There were no differences $(P>0.05)$ found in amount of MUFA, stearic acid (C18:0), linoleic acid (C18:2), $\alpha$-linolenic acid (C18:3), or PUFA. However, the numerically lower PUFA content in meat from cattle fed the control diet compared with all other diets is a commonly seen pattern (Schoonmaker et al., 2010; Mello et al., 2012; Buttrey et al., 2013; Domenech-Perez et al., 2017). In the present study, this pattern was not sufficiently consistent to be significant $(P=0.31)$. 
Table 2. Amount ${ }^{1}$ of fatty acids from strip loin steaks

\begin{tabular}{|c|c|c|c|c|c|c|c|}
\hline \multirow[b]{2}{*}{ Fatty acid } & \multicolumn{5}{|c|}{ Dietary treatment } & \multirow[b]{2}{*}{ SEM } & \multirow[b]{2}{*}{$P$-value } \\
\hline & Control & WDGS $^{3}$ & $\operatorname{Bran}^{3}$ & DDGS $^{3}$ & HP-DDGS $^{3}$ & & \\
\hline$\overline{\mathrm{C} 14: 0}$ & 225.41 & 226.26 & 195.39 & 185.20 & 239.57 & 34.94 & 0.52 \\
\hline $\mathrm{C} 15: 0$ & 35.01 & 42.34 & 30.90 & 28.50 & 35.64 & 3.77 & 0.17 \\
\hline C15:1 & 70.80 & 65.27 & 71.25 & 67.19 & 50.76 & 15.08 & 0.87 \\
\hline $\mathrm{C} 16: 0$ & 1808.83 & 1958.65 & 1684.94 & 1593.28 & 1898.69 & 185.38 & 0.64 \\
\hline $\mathrm{C} 16: 1$ & 246.74 & 202.24 & 195.16 & 184.05 & 220.73 & 23.47 & 0.41 \\
\hline C17:0 & $91.42^{\mathrm{ab}}$ & $132.86^{\mathrm{a}}$ & $77.81^{\mathrm{b}}$ & $72.06^{\mathrm{b}}$ & $82.51^{\mathrm{b}}$ & 10.75 & 0.02 \\
\hline C17:1 & 79.63 & 95.76 & 63.40 & 68.26 & 72.10 & 8.83 & 0.16 \\
\hline C18:0 & 787.79 & 1109.47 & 918.64 & 788.79 & 88.87 & 89.60 & 0.15 \\
\hline $\mathrm{C} 18: 1 \mathrm{~T}^{4}$ & 179.98 & 355.21 & 267.81 & 194.52 & 389.10 & 54.84 & 0.08 \\
\hline $\mathrm{C} 18: 1 \mathrm{~V}^{4}$ & 107.08 & 113.75 & 95.37 & 83.76 & 106.82 & 14.45 & 0.63 \\
\hline C18:2 & 286.87 & 440.00 & 405.94 & 386.66 & 544.83 & 53.69 & 0.07 \\
\hline $\mathrm{C} 18: 3$ & 10.04 & 11.80 & 7.60 & 5.54 & 17.52 & 3.72 & 0.27 \\
\hline $\mathrm{C} 20: 3$ & 20.14 & 22.66 & 23.10 & 20.95 & 19.38 & 2.98 & 0.88 \\
\hline C22:4 & 10.17 & 7.61 & 11.46 & 10.03 & 5.46 & 2.01 & 0.30 \\
\hline $\mathrm{C} 22: 5$ & 18.20 & 12.65 & 16.15 & 13.23 & 11.21 & 2.56 & 0.26 \\
\hline Total & $6,720.02$ & $7,932.05$ & $6,731.93$ & $6,189.55$ & $7,416.18$ & 660.07 & 0.43 \\
\hline $\mathrm{SFA}^{4}$ & $2,963.80$ & $3,492.94$ & $2,924.14$ & $2,683.05$ & $3,170.17$ & 303.33 & 0.45 \\
\hline MUFA $^{4}$ & $3,294.90$ & $3,833.14$ & $3,221.83$ & $2,944.63$ & $3,532.87$ & 301.18 & 0.36 \\
\hline PUFA $^{4}$ & 461.32 & 605.97 & 585.97 & 561.87 & 713.13 & 76.86 & 0.31 \\
\hline
\end{tabular}

a,b Means in the same row with different superscripts differ $(P<0.05)$.

${ }^{1}$ Amount (mg/100 g tissue) of fatty acid in powdered loin sample determined by gas chromatography.

${ }^{2}$ Three cattle per pen were selected.

${ }^{3}$ WDGS $=$ wet distillers grains plus solubles, Bran = corn bran plus solubles, DDGS = dried distillers grains plus solubles, HP-DDGS $=$ high-protein distillers grains plus solubles.

${ }^{4} \mathrm{C} 18: 1 \mathrm{~T}$ = elaidic acid; $\mathrm{C} 18: 1 \mathrm{~V}=$ vaccenic acid; SFA = saturated fatty acids; MUFA = monounsaturated fatty acids.

A trend was identified at $P=0.08$ for elaidic acid $(\mathrm{C} 18: 1 \mathrm{~T})$, where steaks from cattle fed HP-DDGS had greater values for C18:1T than steaks from cattle fed Control $(389.10 \mathrm{mg} / 100 \mathrm{~g}$ and $179.98 \mathrm{mg} / 100 \mathrm{~g}$, respectively). Similar results were found by Mello et al. (2012) who determined that as increasing levels of WDGS were fed to cattle, C18:1T also increased. Domenech-Perez et al. (2017) also reported that supplementing cattle with $65 \%$ WDGS resulted in greater levels of C18:1T in steaks than the amounts that were found in steaks from cattle fed corn finishing diets.

Dietary treatments were shown to have a trend at $P=0.07$ for linoleic acid (C18:2). Following the same pattern as $\mathrm{C} 18: 1 \mathrm{~T}$, steaks from cattle fed HP-DDGS had the greatest levels of C18:2, followed by WDGS, Bran and DDGS, with steaks from cattle fed Control containing the least amount of C18:2. Linoleic acid totals were also greater for steaks from cattle fed distillers grains compared with corn in multiple other studies (Mello et al., 2012; Domenech-Perez et al., 2017; Ribeiro et al., 2018).

There were no differences in PUFA content $(P=0.31)$. Popowski (2011) noted a difference $(P<0.001)$ in the levels of PUFA with meat from cattle fed HP-DDGS having a greater level of PUFA than meat from cattle fed a corn control. Differences in $\mathrm{C} 17: 0$ and $\mathrm{C} 18: 1 \mathrm{~T}$ are indicative of dietary influences on fatty acid composition. However, there was sufficient variation among samples for PUFA and C18:2 where trends, while apparent, were not significantly different.

It has been stated that fatty acid composition of meat from ruminant animals is largely controlled by the feedstuff used (Jenkins, 1993; Houben et al., 2000; Buttrey et al., 2013; Ribeiro et al., 2018). When greater amounts of grain are included in ruminant diets, the $\mathrm{pH}$ of the rumen will become more acidic which reduces the biohydrogenation of fatty acids (Plascencia et al., 1999; Atkinson et al, 2006). As a result, more unsaturated fatty acids reach the duodenum where they interact with bile salt micelles and are more efficiently absorbed into the bloodstream (Zinn et al., 2000). Vander Pol et al. (2009) found that by feeding WDGS, a greater amount of PUFA was reaching the duodenum. These findings were supported by Duckett et al. (2002) when they found that feeding higher lipid diets increased duodenal flow of palmitic, stearic, oleic, linoleic, and arachidonic acid by $30 \%$. Once the fatty acids have reached the bloodstream, 
they can then be deposited into the muscle (Enser et al., 1996; Scollan et al., 2006).

\section{Lipid Oxidation (TBARS)}

A retail-by-treatment interaction $(P<0.001)$ was observed for lipid oxidation (Table 3). After $7 \mathrm{~d}$ of RD, steaks from cattle fed HP-DDGS had greater TBARS values $(P<0.05)$ than all other treatments except steaks from WDGS fed cattle. There were no differences in lipid oxidation between steaks from cattle fed WDGS, Bran, and DDGS. The least lipid oxidation occurred in steaks from cattle fed Control, which were different $(P<0.05)$ from steaks from all other dietary treatments except those from the DDGS treatment. These results are consistent with results from Popowski (2011) where ground beef from cattle fed HP-DDGS had greater levels of TBARS than ground beef from steers fed corn or DDGS $(P<0.001)$.

An aging time-by-days of RD interaction was also noted $(P<0.001)$ where steaks aged for $23 \mathrm{~d}$ with $7 \mathrm{~d}$ of $\mathrm{RD}$ had the greatest TBARS values

Table 3. Lipid oxidation value (TBARS; mg malonaldehyde/kg of meat) of strip loin steaks ${ }^{1}$

\begin{tabular}{lccc}
\hline \hline & \multicolumn{3}{c}{ Days in retail display } \\
\cline { 2 - 4 } Dietary treatment & 0 & 4 & 7 \\
\hline Control & $0.67^{\mathrm{a}}$ & $1.45^{\mathrm{a}}$ & $2.38^{\mathrm{c}}$ \\
WDGS $^{2}$ & $0.77^{\mathrm{a}}$ & $2.04^{\mathrm{a}}$ & $4.27^{\mathrm{a}}$ \\
Bran $^{2}$ & $0.73^{\mathrm{a}}$ & $2.08^{\mathrm{a}}$ & $3.86^{\mathrm{b}}$ \\
DDGS $^{2}$ & $0.85^{\mathrm{a}}$ & $1.64^{\mathrm{a}}$ & $3.19^{\mathrm{bc}}$ \\
HP-DDGS $^{2}$ & $0.80^{\mathrm{a}}$ & $2.40^{\mathrm{a}}$ & $5.15^{\mathrm{a}}$ \\
\hline
\end{tabular}

${ }^{\mathrm{a}-\mathrm{c}}$ Means in the same column with different superscripts are different $(P<0.05)$, SEM $=0.23$.

${ }^{1}$ Three cattle per pen were selected.

${ }^{2} \mathrm{WDGS}=$ wet distillers grains plus solubles; Bran $=$ corn bran plus solubles; DDGS $=$ dried distillers grains plus solubles; HP-DDGS $=$ high-protein distillers grains plus solubles. compared with all other periods. Within each aging period, steaks with $7 \mathrm{~d}$ of $\mathrm{RD}$ had the highest TBARS values followed by steaks with $4 \mathrm{~d}$ of RD having greater values than steaks from $0 \mathrm{RD}$.

\section{Instrument Color}

Muscle $L^{*}$ and $a^{*}$ exhibited dietary treatment by RD interactions $(P<0.001$; Tables 4 and 5). The $L^{*}$ values for steaks from cattle fed WDGS were greater (lighter; $P<0.05$ ) than all treatments at $0 \mathrm{~d}$ of RD, other than steaks from cattle fed HP-DDGS which were similar. There were no differences $(P$ $>0.05)$ in lightness $\left(L^{*}\right)$ among the other dietary treatments at $0 \mathrm{~d}$ of RD. After $7 \mathrm{~d}$ of RD, steaks from cattle fed HP-DDGS had greater $L^{*}$ values than steaks from the Control cattle $(P=0.004)$. Gill et al. (2008) found that meat from cattle fed $15 \%$ distillers grains had lighter meat than cattle fed steam-flaked corn $(P<0.05)$. These results contrast findings by Depenbusch et al. (2009) who reported, as the proportion of DDGS fed to heifers increased linearly from $0 \%$ to $75 \%$, there was a linear decrease in lightness (lower $\left.L^{*}\right)$ at RD $0(P=0.04)$.

Redness $\left(a^{*}\right)$ was greater $(P<0.05)$ for steaks from cattle fed DDGS than steaks from the Bran treatment, HP-DDGS treatment, and Control on $0 \mathrm{~d}$ of RD. The HP-DDGS steaks had lower $(P<0.05)$ redness values than all other treatments following $7 \mathrm{~d}$ of RD, while Control steaks had the greatest $a^{*}$ value $(P<0.05$; Figure 2$)$. Popowski (2011) determined that after $4 \mathrm{~d}$ of RD, steaks from steers fed HP-DDGS and DDGS had lower $(P<0.01) a^{*}$ values than steaks from steers fed a corn control. This is consistent with the findings of multiple studies that indicated a decrease in redness after the utilization of distillers grains in cattle diets (Depenbusch et al., 2009; Leupp et al., 2009; Mello et al., 2012).

Table 4. Objective lightness $\left(L^{*}\right)$ of strip loin steaks through $7 \mathrm{~d}$ of retail display

\begin{tabular}{lccccccc}
\hline \hline & \multicolumn{7}{c}{ Days on retail display } \\
\cline { 2 - 8 } Treatment & 0 & 1 & 2 & 3 & 4 & 5 & 6 \\
\hline Control & 43.56 & 43.46 & 43.69 & $43.73^{\text {ab }}$ & 43.43 & 43.21 & 43.36 \\
WDGS $^{2}$ & 44.59 & 44.12 & 43.92 & $44.14^{\mathrm{a}}$ & 43.72 & 43.76 & 43.56 \\
Bran $^{2}$ & 43.84 & 43.03 & 42.87 & $42.99^{\mathrm{b}}$ & 43.12 & 42.96 & 43.31 \\
DDGS $^{2}$ & 43.77 & 43.36 & 43.17 & $43.09^{\mathrm{b}}$ & 43.15 & 43.33 & $43.07^{\mathrm{ab}}$ \\
HP-DDGS $^{2}$ & 43.86 & 43.68 & 43.46 & $43.67^{\mathrm{ab}}$ & 43.47 & 43.76 & $43.45^{\mathrm{bc}}$ \\
$P$-value & 0.08 & 0.09 & 0.07 & 0.02 & 0.50 & 0.13 & $43.82^{\mathrm{ab}}$ \\
\hline
\end{tabular}

${ }^{\mathrm{a}-\mathrm{c}}$ Means in the same column with different superscripts are different $(P<0.05), \mathrm{SEM}=0.27$.

${ }^{1}$ Three cattle per pen were selected.

${ }^{2} \mathrm{WDGS}=$ wet distillers grains plus solubles; Bran = corn bran plus solubles; DDGS = dried distillers grains plus solubles; HP-DDGS = high-protein distillers grains plus solubles.

$n=18 /$ treatment. 
Table 5. Objective redness $\left(a^{*}\right)$ of strip loin through $7 \mathrm{~d}$ of retail display

\begin{tabular}{lcccccccc}
\hline \hline & \multicolumn{7}{c}{ Days on retail display } \\
\cline { 2 - 8 } Treatment & 0 & 1 & 2 & 3 & 4 & 5 & 6 \\
\hline Control & $21.40^{\mathrm{c}}$ & $21.06^{\mathrm{c}}$ & $20.37^{\mathrm{c}}$ & 19.94 & 19.71 & $18.84^{\mathrm{a}}$ & $17.88^{\mathrm{a}}$ & $16.95^{\mathrm{a}}$ \\
WDGS $^{2}$ & $22.15^{\mathrm{ab}}$ & $21.63^{\mathrm{abc}}$ & $20.65^{\mathrm{bc}}$ & 20.38 & 19.80 & $18.44^{\mathrm{ab}}$ & $16.68^{\mathrm{b}}$ & $15.21^{\mathrm{b}}$ \\
Bran $^{2}$ & $21.70^{\mathrm{bc}}$ & $21.90^{\mathrm{ab}}$ & $21.04^{\mathrm{ab}}$ & 20.48 & 19.75 & $18.00^{\mathrm{bc}}$ & $16.30^{\mathrm{b}}$ & $15.03^{\mathrm{b}}$ \\
DDGS $^{2}$ & $22.69^{\mathrm{a}}$ & $22.28^{\mathrm{a}}$ & $21.43^{\mathrm{a}}$ & 20.55 & 20.08 & $18.82^{\mathrm{a}}$ & $16.33^{\mathrm{b}}$ & $15.13^{\mathrm{b}}$ \\
HP-DDGS $^{2}$ & $21.91^{\mathrm{bc}}$ & $21.29^{\mathrm{bc}}$ & $20.88^{\mathrm{bc}}$ & 20.10 & 19.27 & $17.43^{\mathrm{c}}$ & $14.58^{\mathrm{c}}$ & $12.58^{\mathrm{c}}$ \\
$c P$-value & 0.01 & 0.05 & 0.02 & 0.55 & 0.20 & $<0.01$ & $<0.01$ & $<0.01$ \\
\hline
\end{tabular}

${ }^{\mathrm{a}-\mathrm{u}}$ Means in the same column with different superscripts are different $(P<0.05), \mathrm{SEM}=0.30$.

${ }^{1}$ Three cattle per pen were selected.

${ }^{2}$ WDGS = wet distillers grains plus solubles; Bran = corn bran plus solubles; DDGS = dried distillers grains plus solubles; HP-DDGS = high-protein distillers grains plus solubles.

$n=18 /$ treatment.

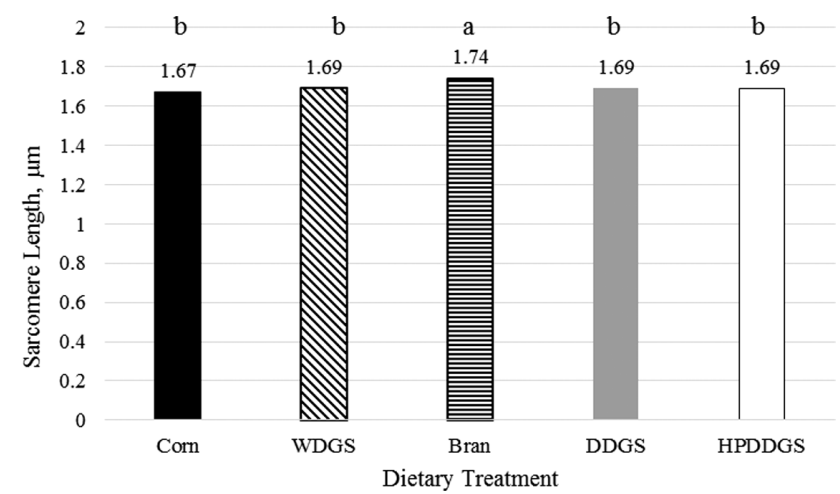

Figure 2. Sarcomere length from strip loins aged for $2 \mathrm{~d}$ with $0 \mathrm{~d}$ retail display $(P<0.10 ; \mathrm{SEM}=0.02)$.

A three-way interaction of dietary treatment, aging time, and days of RD was identified for $b^{*}$ values $(P=0.006)$. At 2 and $23 \mathrm{~d}$ aging with $0 \mathrm{~d}$ RD there were no differences among dietary treatments $(P>0.05)$. However, during $9 \mathrm{~d}$ of aging with $0 \mathrm{~d}$ of RD, steaks from cattle supplemented with DDGS was significantly more yellow than steaks from Control fed cattle $(P=0.03)$. For steaks with $2 \mathrm{~d}$ of aging and $7 \mathrm{~d}$ of RD, Control, WDGS, and DDGS were all significantly more yellow than the HP-DDGS treatment. At $9 \mathrm{~d}$ of aging with $7 \mathrm{~d}$ of RD, steaks from Bran and DDGS had greater yellowness values $(P<0.05)$ compared with HP-DDGS. There were no differences $(P>$ $0.05)$ between dietary treatments at $23 \mathrm{~d}$ of aging and $7 \mathrm{~d}$ of RD.

\section{Visual Discoloration}

Discoloration results for all aging periods, days in $\mathrm{RD}$, and dietary treatments are reported in Table 6. After $7 \mathrm{~d}$ of RD following 2 and $9 \mathrm{~d}$ of aging, steaks from cattle fed HP-DDGS had more discoloration $(P<0.05)$ than all other treatments, which were similar. Following $23 \mathrm{~d}$ of aging, steaks from cattle fed HP-DDGS had the most discoloration and all treatments except WDGS were more discolored than Control $(P<0.05)$ after 6 and $7 \mathrm{~d}$ of RD. As RD progressed, more variation in discoloration was observed among steaks as some steaks discolored to a greater extent than others. Consequently, large differences in mean discoloration (e.g., RD 7 after $23 \mathrm{~d}$ of aging) were not significantly different. These results are consistent with Popowski (2011) who found an increase in surface discoloration for steaks from steers fed HP-DDGS compared with steaks from steers fed either DDGS or a corn control $(P<0.01)$.

Meat purchasing decisions have been noted to be largely affected when fresh meat color contains $20 \%$ surface discoloration, resulting in a decrease in sales by up to $50 \%$ (Hood and Riordan, 1973). In this study, after only $9 \mathrm{~d}$ of aging and $7 \mathrm{~d}$ of RD, steaks from cattle fed HP-DDGS were already reaching discoloration values of $19.9 \%$. After $23 \mathrm{~d}$ of aging, steaks from all dietary treatments except Control and WDGS surpassed the $20 \%$ discoloration mark after $6 \mathrm{~d}$ of RD.

Lipid oxidation by-products can affect color, aroma, flavor, and overall shelf life (Morrissey et al., 1998; Gray et al., 1996; Ladeira et al., 2014). Campo et al. (2006) surmised that TBARS values of $2.28 \mathrm{mg} / \mathrm{kg}$ were considered the limiting threshold of oxidized beef unacceptability. In this study, steaks from cattle fed HP-DDGS surpassed this limit $(2.40 \mathrm{mg}$ malonaldehyde $/ \mathrm{kg}$ ) after $4 \mathrm{~d}$ of $\mathrm{RD}$ while no other treatments reached this level until $7 \mathrm{~d}$ of RD. After $7 \mathrm{~d}$ of RD, all treatments had reached the threshold of acceptability. Lipid oxidation in meat has been strongly linked to myoglobin oxidation, meaning the oxidation of one can accelerate oxidation of the other (Faustman et al., 2010). These data, along with our discoloration results as described in the previous section, 
Table 6. Discoloration (\%) of strip loin steaks with 2, 9, and $23 \mathrm{~d}$ of aging at 5, 6, and $7 \mathrm{~d}$ of retail display

\begin{tabular}{|c|c|c|c|c|c|c|c|c|c|}
\hline \multirow{2}{*}{$\frac{\text { Aging period }}{\text { Days in retail display }}$} & \multicolumn{3}{|c|}{2} & \multicolumn{3}{|c|}{9} & \multicolumn{3}{|c|}{23} \\
\hline & 5 & 6 & 7 & 5 & 6 & 7 & 5 & 6 & 7 \\
\hline \multicolumn{10}{|l|}{ Dietary treatments } \\
\hline Control & $0.29^{\mathrm{a}}$ & $0.72^{\mathrm{a}}$ & $1.59^{\mathrm{b}}$ & $0.13^{\mathrm{a}}$ & $0.68^{\mathrm{b}}$ & $1.68^{\mathrm{b}}$ & $3.13^{\mathrm{a}}$ & $15.75^{\mathrm{c}}$ & $38.85^{\mathrm{c}}$ \\
\hline WDGS $^{2}$ & $0.47^{\mathrm{a}}$ & $1.77^{\mathrm{a}}$ & $4.74^{\mathrm{b}}$ & $0.31^{\mathrm{a}}$ & $1.64^{\mathrm{ab}}$ & $5.67^{\mathrm{b}}$ & $6.02^{\mathrm{a}}$ & $34.45^{\mathrm{bc}}$ & $63.63^{\mathrm{b}}$ \\
\hline $\operatorname{Bran}^{2}$ & $0.07^{\mathrm{a}}$ & $1.06^{\mathrm{a}}$ & $2.89^{\mathrm{b}}$ & $0.87^{\mathrm{a}}$ & $3.26^{\mathrm{ab}}$ & $6.79^{\mathrm{b}}$ & $18.98^{\mathrm{a}}$ & $46.24^{\mathrm{ab}}$ & $68.30^{\mathrm{ab}}$ \\
\hline DDGS $^{2}$ & $0.59^{\mathrm{a}}$ & $1.92^{\mathrm{a}}$ & $4.82^{\mathrm{b}}$ & $0.15^{\mathrm{a}}$ & $1.92^{\mathrm{ab}}$ & $4.83^{\mathrm{b}}$ & $13.88^{\mathrm{a}}$ & $45.05^{\mathrm{ab}}$ & $74.19^{\mathrm{ab}}$ \\
\hline HP-DDGS $^{2}$ & $0.44^{\mathrm{a}}$ & $4.86^{\mathrm{a}}$ & $15.32^{\mathrm{a}}$ & $1.74^{\mathrm{a}}$ & $7.67^{\mathrm{a}}$ & $19.88^{\mathrm{a}}$ & $16.30^{\mathrm{a}}$ & $64.31^{\mathrm{a}}$ & $85.79^{a}$ \\
\hline
\end{tabular}

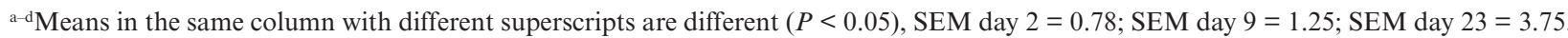

${ }^{1}$ Three cattle per pen were selected.

${ }^{2} \mathrm{WDGS}=$ wet distillers grains plus solubles; Bran = corn bran plus solubles; DDGS = dried distillers grains plus solubles; HP-DDGS = high-protein distillers grains plus solubles.

follow a similar pattern where beef from cattle fed distillers grain and other ethanol co-products have the greatest levels of lipid oxidation and discoloration, with HP-DDGS having the most detrimental effects for both.

Since lipid oxidation has been tightly linked to myoglobin oxidation, it was expected that a lower fat feedstuff would result in more stable meat color (Greene, 1969). However, as noted above, the trend $(P=0.07)$ of an increase of C18:2 in meat samples from cattle fed HP-DDGS could explain this discoloration pattern. It has been well documented that an increase in PUFA can result in increased lipid oxidation (Morrissey et al., 1998; Faustman et al., 2010). Lipid oxidation can be a major contributor to myoglobin oxidation due to the creation of free radicals that interact with myoglobin, oxidizing it from the oxymyoglobin form into metmyoglobin (Faustman et al., 2010). Nute et al. (2007) reported that meat from animals fed diets with greater levels of PUFA present is more susceptible to being oxidized resulting in greater discoloration. Although there were no significant differences among dietary treatments for total PUFA, the trend for increased levels of C18:2 could be the cause of the increased surface discoloration.

In conclusion, feeding cattle HP-DDGS at $40 \%$ inclusion increased lipid oxidation and discoloration in steaks compared with those fed a corn control finishing diet. Although there were no statistical differences in the fatty acid profile across treatments, there was a trend that meat from cattle fed HP-DDGS had greater amounts of C18:2 than steaks from cattle fed a corn control diet. These findings could be the cause of the decreased display life of steaks from cattle fed HP-DDGS at longer aging times and RD times. While there were no detriments in terms of tenderness, the increase in lipid oxidation and color instability could result in significant economic ramifications due to shorter shelf life.

Conflict of interest statement. None declared.

\section{LITERATURE CITED}

Ahn, D. U., D. G. Olson, C. Jo, X. Chen, C. Wu, and J. I. Lee. 1998. Effect of muscle type, packaging, and irradiation on lipid oxidation, volatile production, and color in raw pork patties. Meat Sci. 49:27-39. doi:10.1016/ S0309-1740(97)00101-0

AOAC. 1990. Official methods of analysis. 15th ed. Arlington, VA: Association of Official Analytical Chemists.

Atkinson, R. L., E. J. Scholljegerdes, S. L. Lake, V. Nayigihugu, B. W. Hess, and D. C. Rule. 2006. Site and extent of digestion, duodenal flow, and intestinal disappearance of total and esterified fatty acids in sheep fed a high-concentrate diet supplemented with high-linoleate safflower oil. J. Anim. Sci. 84:387-396. doi:10.2527/2006.842387x

Buttrey, E. K., K. H. Jenkins, J. B. Lewis, S. B. Smith, R. K. Miller, T. E. Lawrence, F. T. McCollum, 3rd, P. J. Pinedo, N. A. Cole, and J. C. MacDonald. 2013. Effects of $35 \%$ corn wet distillers grains plus solubles in steam-flaked and dry-rolled corn-based finishing diets on animal performance, carcass characteristics, beef fatty acid composition, and sensory attributes. J. Anim. Sci. 91:1850-1865. doi:10.2527/jas.2013-5029

Campo, M. M., G. R. Nute, S. I. Hughes, M. Enser, J. D. Wood, and R. I. Richardson. 2006. Flavour perception of oxidation in beef. Meat Sci. 72:303-311. doi:10.1016/j. meatsci.2005.07.015

Cereal Process Technologies. 2016. High protein distillers dried grains and other co-products from front-end fractionation. Cereal Process Technologies, LLC. 20th Annual Distillers Grains Symposium. - [accessed May 10, 2018]. https://distillersgrains.org/symposium/

Cereal Process Technologies. 2018. [accessed May 10, 2018]. http://www.cerealprocess.com/fractionation/

Chao, M. D., K. I. Domenech-Perez, L. S. Senaratne-Lenagala, and C. R. Calkins. 2017. Feeding wet distillers grains plus solubles to cattle contributes to sarcoplasmic reticulum membrane instability. Animal Prod. Sci. doi:10.1071/ AN16784

Cross, H. R., R. L. West, and T. R. Dutson. 1981. Comparison of methods for measuring sarcomere length 
in beef semitendinosus muscle. Meat Sci. 5:261-266. doi:10.1016/0309-1740(81)90016-4.

Depenbusch, B. E., C. M. Coleman, J. J. Higgins, and J. S. Drouillard. 2009. Effects of increasing levels of dried corn distillers grains with solubles on growth performance, carcass characteristics, and meat quality of yearling heifers. J. Anim. Sci. 87:2653-2663. doi:10.2527/ jas. 2008-1496

Dolazza, R. M., and Lorenzen, C. L. 2014. Can samples be powdered to determine sarcomere length? J. Anim. Sci. 92:129-130.

Domenech-Pérez, K. I., C. R. Calkins, M. D. Chao, M. E. Semler, K. A. Varnold, and G. E. Erickson. 2017. Impact of feeding de-oiled wet distillers grains plus solubles on beef shelf life. J. Anim. Sci. 95:709-717. doi:10.2527/jas.2016.0905.

Duckett, S. K., J. G. Andrae, and F. N. Owens. 2002. Effect of high-oil corn or added corn oil on ruminal biohydrogenation of fatty acids and conjugated linoleic acid formation in beef steers fed finishing diets. J. Anim. Sci. 80:33533360. doi: $10.2527 / 2002.80123353 x$

Enser, M., K. Hallett, B. Hewitt, G. A. Fursey, and J. D. Wood. 1996. Fatty acid content and composition of English beef, lamb and pork at retail. Meat Sci. 42:443-456. doi:10.1016/0309- 1740(95)00037-2

Faustman, C., Q. Sun, R. Mancini, and S. P. Suman. 2010. Myoglobin and lipid oxidation interactions: mechanistic bases and control. Meat Sci. 86:86-94. doi:10.1016/j. meatsci.2010.04.025.

Folch, J., M. Lees, and G. H. Sloane Stanley. 1957. A simple method for the isolation and purification of total lipides from animal tissues. J. Biol. Chem. 226:497-509.

Ganesan, V., K. A. Rosentrater, and K. Muthukumarappan. 2009. Physical and flow properties of regular and reduced fat distillers dried grains with solubles (DDGS). Food Bioprocess Technol. 2:156-166. doi:10.1007/ s11947-007-0026-X

Gill, R. K., D. L. VanOverbeke, B. Depenbusch, J. S. Drouillard, and A. Dicostanzo. 2008. Impact of beef cattle diets containing corn or sorghum distillers grains on beef color, fatty acid profiles, and sensory attributes. J. Anim. Sci. 86:923-935. doi:10.2527/jas.2007-0244

Gordon, C. M., J. S. Drouillard, R. K. Phebus, K. A. Hachmeister, M. E. Dikeman, J. J. Higgins, and A. L. Reicks. 2002. The effect of Dakota Gold®-brand dried distillers grains with solubles of varying levels on sensory and color characteristics of ribeye steaks. In: Cattlemen's day. Manhattan, Manhattan, KS: Kansas State University; p. 72-74

Gray, J. I., E. A. Gomaa, and D. J. Buckley. 1996. Oxidative quality and shelf life of meats. Meat Sci. 43:S11-S123. doi:10.1016/0309-1740(96)00059-9

Greene, B. E. 1969. Lipid oxidation and pigment changes in raw beef. J. Food Sci. 34:110-113. doi:10.1111/j.1365-2621.1969. tb00898.X

Hood, D. E. R., E. B. Riordan. 1973. Discolouration in pre-packaged beef: measurement by reflectance spectrophotometry and shopper discrimination. J. Food Technol. 8:333-343. doi:10.1111/j.1365-2621.1973.tb01721.x

Houben, J. H., A. van Dijk, G. Eikelenboom, and A. H. HovingBolink. 2000. Effect of dietary vitamin E supplementation, fat level and packaging on colour stability and lipid oxidation in minced beef. Meat Sci. 55:331-336. doi:10.1016/ S0309-1740(99)00161-8
Jenkins, T. C. 1993. Lipid metabolism in the rumen. J. Dairy Sci. 76:3851-3863. doi:10.3168/jds.S0022-0302(93)77727-9.

Klopfenstein, T. J., G. E. Erickson, and V. R. Bremer. 2008. Board-invited review: use of distillers by-products in the beef cattle feeding industry. J. Anim. Sci. 86:1223-1231. doi:10.2527/jas.2007-0550.

Ladeira, M. M., L. C. Santarosa, M. L. Chizzotti, E. M. Ramos, O. R. Machado Neto, D. M. Oliveira, J. R. Carvalho, L. S. Lopes, and J. S. Ribeiro. 2014. Fatty acid profile, color and lipid oxidation of meat from young bulls fed ground soybean or rumen protected fat with or without monensin. Meat Sci. 96:597-605. doi:10.1016/j. meatsci.2013.04.062.

Leupp, J. L., G. P. Lardy, M. L. Bauer, K. K. Karges, M. L. Gibson, J. S. Caton, and R. J. Maddock. 2009. Effects of distillers dried grains with solubles on growing and finishing steer intake, performance, carcass characteristics, and steak color and sensory attributes. J. Anim. Sci. 87:4118-4124. doi:10.2527/jas.2009-2149.

Mello, A. S., Jr, C. R. Calkins, B. E. Jenschke, T. P. Carr, M. E. Dugan, and G. E. Erickson. 2012. Beef quality of calf-fed steers finished on varying levels of corn-based wet distillers grains plus solubles. J. Anim. Sci. 90:4625-4633. doi:10.2527/jas.2010-3239.

Metcalfe, L. D., A. A. Schmitz, and J. R. Pelka. 1966. Rapid separation of fatty acid esters from lipids for gas chromatography analysis. Anal. Chem. 38:514-515. doi:10.1021/ ac60235a044

Morrison, W. R., and L. M. Smith. 1964. Preparation of fatty acid methyl esters and dimethylacetals from lipids with boron fluoride-methanol. J. Lipid Res. 5:600-608.

Morrissey, P. A., P. J. A. Sheehy, K. Galvin, J. P. Kerry, and D. J. Buckley. 1998. Lipid stability in meat and meat products. Meat Sci. 49, No. Suppl. 1:S73-S86. doi:10.1016/ S0309-1740(98)90039-0

NAMP. 2011. The meat buyers guide. Reston, VA: North American Meat Processors Association.

Nute, G. R., R. I. Richardson, J. D. Wood, S. I. Hughes, R. G. Wilkinson, S. L. Cooper, and L. A. Sinclair. 2007. Effect of dietary oil source on the flavour and the colour and lipid stability of lamb meat. Meat Sci. 77:547-555. doi:10.1016/j.meatsci.2007.05.003.

Parrish, F. C., Selvig, C. J., Culler, R. D., and Zeece, M. G. 1981. CAF activity, calcium concentration, and the 30,000-dalton component of tough and tender bovine longissimus muscle. J. Food Sci., 46:308-311. doi:10.1111/j.1365-2621.1981.tb14593.x

Plascencia, A., M. Estrada, and R. A. Zinn. 1999. Influence of free fatty acid content on the feeding value of yellow grease in finishing diets for feedlot cattle. J. Anim. Sci. 77:2603-2609. doi:10.2527/1999.77102603x

Ponnampalam, E., Steele, D. B., Burgdorf, D., and McCalla, D. 2004. Effect of germ and fiber removal on production of ethanol from corn. Appl. Biochem. Biotechnol. 113116:837-842. doi:10.1385/ABAB:115:1-3:0837

Popowski, J. M. 2011. Effect of feeding high protein dried distillers grains in beef finishing diets on carcass characteristics, beef quality, and sensory attributes [thesis]. University of Minnesota.

Rendleman, C. M., and H. Shapouri. 2007. New Technologies in Ethanol Production. Agricultural Economic Report Number 842, Office of the Chief Economist, USDA.

Ribeiro, F. A. 2017. Effects of dietary fat source on beef quality. [dissertation]. Sao Paulo: University. 
Ribeiro, F. A., K. I. Domenech-Pérez, C. J. ContrerasCastillo, E. K. Wilkerson, H. R. Voegele, K. Ballard Hart, N. J. Herrera, and C. R. Calkins. 2018. Effects of dietary fat source on beef strip loin steak display life. J. Anim. Sci. 96:2665-2674. doi:10.1093/jas/sky113

Robinson, P. H., Karges, K., and Gibson, M. L. 2008. Nutritional evaluation of four co-product feedstuffs from the motor fuel ethanol distillation industry in the Midwestern USA. Anim. Feed Sci. Technol. 146: 345-352. doi:10.1016/j.anifeedsci.2008.01.004

Schoonmaker, J. P., A. H. Trenkle, and D. C. Beitz. 2010. Effect of feeding wet distillers grains on performance, marbling deposition, and fatty acid content of beef from steers fed low- or high-forage diets. J. Anim. Sci. 88:3657-3665. doi:10.2527/jas.2010-2896

Scollan, N., J. F. Hocquette, K. Nuernberg, D. Dannenberger, I. Richardson, and A. Moloney. 2006. Innovations in beef production systems that enhance the nutritional and health value of beef lipids and their relationship with meat quality. Meat Sci. 74:17-33. doi:10.1016/j.meatsci.2006.05.002

Segers, J. R., R. L. Stewart, Jr, C. A. Lents, T. D. Pringle, M. A. Froetschel, B. K. Lowe, R. O. McKeith, and A. M. Stelzleni. 2011. Effect of long-term corn by-product feeding on beef quality, strip loin fatty acid profiles, and shelf life. J. Anim. Sci. 89:3792-3802. doi:10.2527/ jas.2011-4154

Senaratne-Lenagala, L. S. 2012. Mechanism and control of beef toughening during retail display in high oxygen modified atmosphere packages. Ph.D. Dissertation, University of Nebraska, Lincoln NE. http://digitalcommons.unl.edu/ animalscidiss/54/

U.S. Grains Council. 2012. A guide to distiller's dried grains plus solubles. 3rd ed. - [accessed May 22, 2018]. https:// grains.org/wpcontent/uploads- /2018/01/Complete-2012DDGS-Handbook.pdf

Vander Pol, K. J., M. K. Lube, G. I. Crawford, G. E. Erickson, and T. J. Klopfenstein. 2009. Performance and digestibility characteristics of finishing diets containing distillers grains, composites of corn processing coproduces, or supplemental corn oil. J. Anim. Sci. 87:639-652. doi:10.2527/jas.2008-1036.

Wheeler, T. L., and M. Koohmaraie. 1999. The extent of proteolysis is independent of sarcomere length in lamb longissimus and psoas major. J. Anim. Sci. 77:2444-2451. doi: $10.2527 / 1999.7792444 x$

Zinn, R. A., S. K. Gulati, A. Plascencia, and J. Salinas. 2000. Influence of ruminal biohydrogenation on the feeding value of fat in finishing diets for feedlot cattle. J. Anim. Sci. 78:1738-1746. doi:10.2527/2000.7871738x 